\title{
Peran Pet Attachment Terhadap Kebahagiaan Pemilik Hewan Peliharaan di Kota Banjarmasin
}

\author{
Arief Tribudiman, Rahmadi, dan Mahdia Fadhila \\ Universitas Islam Negeri Antasari Banjarmasin
}

\begin{abstract}
Keeping animals, especially cats, has been demonstrated by the Prophet. This certainly saves goodness in it. If you see the relationship between humans and animals that are intertwined in a longer period of time will cause attachment in it or we call it a pet attachment. So the purpose of this study will look at how the role of pet attachments on the happiness of pet owners. This research is a field research, with a qualitative descriptive approach. The technique of selecting research subjects using purposive sampling technique, the number of samples as many as 22 people and after screening tests using a stickiness scale that has been validated and reliable (0.807), obtained 5 people included in the category. Furthermore, 2 subjects who were willing to take part in the research. Data collection used was semi-structured interviews, nonparticipant observation, and documentation. The results showed a description of pet attachments in pet owners including physical contact, selection criteria, reactions to separation and loss, effects on physical and psychological health. The description of the happiness of pet owners can be seen in the aspects of happiness, which consists of aspects of positive emotion, engagement, positive relationships, meaning and accomplishment. All aspects are fulfilled from the attachment to the pet (pet attachment), causing happiness to the pet owner.
\end{abstract}

Keywords: Pet Attachments; Happiness; Pet Owners.

\begin{abstract}
Abstrak
Memelihara hewan terutama kucing telah di contohkan oleh Rasulullah saw. Hal ini tentu menyimpan kebaikan di dalamnya. Apabila melihat hubungan antara manusia-hewan yang terjalin dalam kurun waktu yang semakin lama akan menimbulkan kelekatan di dalamnya atau kita sebut sebagai pet attachment. Maka tujuan penelitian ini akan melihat bagaimana peran dari pet attachment terhadap kebahagiaan pemilik hewan peliharaan tersebut. Penelitian ini merupakan penelitian lapangan (field research), dengan pendekatan deskriptif kualitatif. Teknik penjaringan subjek penelitian menggunakan teknik purposive sampling, jumlah sampel sebanyak 22 orang dan setelah dilakukan screening test menggunakan skala kelekatan yang telah tervalidasi dan reliable $(0,807)$, diperoleh 5 orang yang termasuk kategori. Selanjutnya 2 orang subjek yang bersedia mengikuti penelitian Pengumpulan data yang digunakan adalah wawancara semi terstruktur, observasi non partisipan, dan dokumentasi. Hasil penelitian menunjukkan gambaran pet attachment pada pemilik hewan peliharaan meliputi adanya kontak fisik, kriteria pilihan, reaksi ketika berpisah dan kehilangan, efek terhadap kesehatan fisik dan psikologis. Adapun gambaran kebahagiaan pemilik hewan peliharaan dapat dilihat pada aspek dari kebahagiaan itu, yang terdiri dari aspek positive emotion, engagement, positive relationship,
\end{abstract}


meaning and accomplishment. Keseluruhan aspek tersebut terpenuhi dari adanya kelekatan pada hewan peliharaan (pet attachment) sehingga menimbulkan kebahagiaan pada pemilik hewan peliharaan.

Kata Kunci: Pet Attachment; Kebahagiaan; Pemilik Hewan Peliharaan.

Memelihara hewan merupakan aktivitas yang digemari oleh berbagai kalangan, hal ini ditandai dengan banyaknya komunitas pecinta hewan tersebut. Beberapa contoh komunitas pecinta binatang yang ada di Kota Banjarmasin antara lain Sahabat Musang Banjarmasin (SAMBA), Cat Shelter Banjarmasin, komunitas Pecinta Reptile, komunitas Pecinta Sugar Glider dan lainnya. Adanya komunitas pecinta hewan ini menunjukkan kepedulian terhadap binatang untuk disayangi, bukan untuk disakiti. Hal ini termuat dalam sebuah hadits yang diriwayatkan oleh Abu Daud dan Tirmidzi, yaitu:

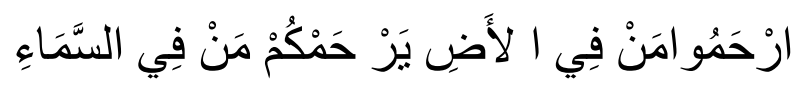

"Sayangilah makhluk yang ada di bumi, maka akan sayang padamu Dzat yang di langit" (HR. Abu Daud dan Tirmidzi).

Bentuk kasih sayang yang dapat kita lihat dari Nabi Muhammad Saw. disini ialah bagaimana beliau berperilaku terhadap hewan, dimana dalam suatu riwayat disebutkan bahwa Nabi Muhammad Saw. ketika beliau hendak mengambil jubahnya untuk melaksanakan sholat. Kain jubahnya tersebut ditiduri oleh seekor kucing peliharaan Nabi Muhammad Saw. yang bernama Muezza, sehingga beliau memotong bagian kain dari jubahnya agar tidak mengganggu tidur kucing tersebut. Hal seperti itu dilakukan Nabi Muhammad Saw. sebagai bentuk kasih sayang yang sangat luar biasa dari beliau yang harus kita perhatikan dalam memperlakukan makhluk hidup disini yaitu hewan. Dalam aktivitas lainnya Nabi Muhammad Saw. setiap beliau menerima tamu dirumahnya, beliau selalu menggendong kucing peliharaannya dan ditaruhnya di paha (Kiki, 2019).

Aktivitas memelihara hewan ini bukanlah sebuah hobi yang tidak bermanfaat. Banyak manfaat yang didapatkan dari aktivitas ini. Menurut Setianingrum seseorang dapat memperoleh tiga manfaat dari aktivitas memelihara hewan, yaitu: membantu untuk memulihkan kesehatan dengan cara menerapkan hidup sehat seperti mengajak jalan-jalan ataupun bermain, membantu menghadapi stress dengan menganggap hewan sebagai hiburan dan teman bermain, bersosialisasi dengan lingkungan dan orang-orang baru seperti saat 
memandikan hewan maupun membawanya berjalan-jalan (Hardiana Saraswati Nugrahaeni, 2016).

Penelitian yang dilakukan oleh Rizqi Khoirunnisa Nurlayli \& Diana Savitri Hidayati diperoleh hasil bahwa dari memelihara binatang seseorang akan mendapatkan sebuah dukungan sosial (social support) yang dapat meningkatkan kesehatannya, memelihara kucing dan selain anjing dapat meningkatkan kualitas sosial. Pendapat ini diperkuat oleh McConnell et al yang meneliti well being antara pemilik hewan peliharaan dan yang tidak memiliki hewan peliharaan. Aspek well being terdiri dari aspek depresi, kesepian, self esteem, gejala penyakit fisik, subjective happiness, dan exercise $\mathcal{E}$ physical fitness. Dalam penelitian itu terbukti bahwa orang yang memiliki hewan peliharaan memiliki self-esteem, subjective well being, dan exercise $\mathcal{E}$ physical fitness yang lebih baik daripada yang tidak memiliki hewan peliharaan(Nurlayli \& Hidayati, 2014).

Dukungan sosial sangat erat kaitannya dengan kebutuhan sosial (social need). Kebutuhan sosial menjadi salah satu kebutuhan dari hirarki kebutuhan Maslow, yaitu Belonging and love. Belonging and love ini merupakan kebutuhan menjadi kelompok sosial dan cinta (Nurlayli \& Hidayati, 2014). Pada kenyataannya manusia dari kaum muda dan tua pasti memiliki keinginan untuk mendapatkan kasih sayang dan rasa memiliki. Tidak hanya kasih sayang sesama manusia, tetapi kasih sayang terhadap alam dan makhluk hidup lainnya termasuk hewan.

Komitmen yang dilakukan saat awal mengadopsi hewan peliharaan hingga beberapa waktu kedepannya tentu saja akan membentuk sebuah ikatan emosional yang berlangsung antara individu dengan figur kelekatannya. Ikatan yang terjadi mengikat mereka dalam waktu yang lama. Hubungan kelekatan ini akan terlihat dari perilaku menangis dan mencari, ketika individu terpisah dari figur lekatnya (Yuniarti, 2008).

Pet attachment (kelekatan pada hewan peliharaan) didasari pada teori attachment Bowlby pada manusia. Bowlby mengartikan bahwa attachment sebagai ikatan emosional yang berlangsung antara individu dengan figur kelekatannya. Figur kelekatan ini dapat berupa individu lain ataupun figur lain seperti hewan peliharaan. Adanya pet attachment ini memberikan pemilik hewan peliharaan tersebut suatu keuntungan di dalam hidupnya, yang mana keuntungan ini berbeda dari pada keuntungan yang diperoleh antara individu satu 
dengan yang lainnya, hal itu adalah tidak adanya resiko penolakan, karena seseorang bisa menjadi ragu untuk menjalin hubungan dengan orang lainnya karena takut mengalami penolakan, tetapi ketika membangun hubungan dengan hewan, seseorang hampir tidak akan mengalami resiko penolakan. Selanjutnya ketakutan menerima evaluasi, kecemasan sosial adalah dimana seseorang biasanya akan merasakan tekanan bahwa dirinya akan mendapatkan evaluasi negatif dari orang lain, sehingga dari hubungan seseorang dengan hewan peliharaannya akan memberikan rasa percaya diri seseorang dalam interaksi sosialnya (Nurlayli \& Hidayati, 2014). Tidak adanya resiko penolakan dan rasa percaya diri yang muncul pada seseorang ini akan menjadi hal yang menyebabkan kebahagiaan didalam hidup seseorang, dimana aspek kebahagiaan itu adalah Possitive Emotion (emosi positif), Enggagment (kelekatan), Positive Relationship (hubungan positif), Meaning (hidup yang bermakna) dan Accomplishment (pencapaian/prestasi).

Pemilik kucing di Kota Banjarmasin akan menjadi subjek pada penelitian ini. Melihat bahwa Rasulullah saw. juga pada masanya memiliki kucing peliharaan, maka dari itu bahwa apa yang beliau lakukan pasti terdapat kebaikan di dalamnya. Sehingga peneliti akan mengambil pemilik kucing sebagai subjek penelitian ini.

Berdasarkan uraian latar belakang diatas, bahwa Nabi Muhammad Saw merupakan sosok panutan yang memperlihatkan kepada kita bentuk kasih sayangnya terhadap hewan, yaitu kucing, juga peran kelekatan yang terbentuk dari hewan dan pemilik hewan peliharaan terhadap kebahagiaan, maka peneliti disini tertarik untuk menunjukkan suatu peran yang dihasilkan dari seseorang yang memelihara hewan khususnya kucing dalam bentuk sebuah penelitian yang berjudul "Peran Pet Attachment Terhadap Kebahagiaan Pemilik Kucing Di Kota Banjarmasin".

\section{Metode}

Penelitian ini menggunakan jenis penelitian lapangan (field research) yaitu penelitian yang semua sumber datanya diperoleh berdasarkan interaksi langsung ke lapangan (Rahmadi, 2011). Peneliti terjun langsung ke lapangan atau tempat penelitian untuk meneliti peran Pet Attachment bagi pemilik hewan pemeliharaan. Adapun pendekatan yang digunakan dalam 
penelitian ini adalah pendekatan deskritif kualitatif, yakni prosedur penelitian yang menghasilkan penelitian data berupa kata-kata tertulis atau lisan tentang orang-orang, perilaku yang dapat diamati sehingga menemukan kebenaran yang dapat diterima oleh akal sehat manusia (Margono, 2007). Penentuan jumlah sampel didasarkan pada purposive sampling yaitu berdasarkan kepada kriteria yang dimiliki oleh subjek yang dipilih, karena kriteria tersebut sesuai dengan tujuan penelitian yang akan dilakukan(Herdiansyah, 2015). Adapun kriteria subjek penelitian ini adalah memiliki hewan peliharaan yakni kucing, merawat kucing minimal selama 1 tahun, memiliki Attachment tingkat tinggi dengan hewan peliharaannya yang dibuktikan berdasarkan hasil screening dengan alat ukur skala pet attachment, bersedia menjadi subjek penelitian dengan mengisi informed concent. Teknik pengumpulan data yang digunakan yaitu, wawancara semi tarstruktur, observasi non partisipan, dan dokumentasi.

\section{Hasil}

Berdasarkan jumlah calon subjek penelitian yang mengikuti screening test, maka yang diambil peneliti untuk dijadikan subjek penelitian yakni yang memiliki tingkat kelekatan tinggi dan bersedia menjadi subjek penelitian.

Tabel 1

Jumlah Frekuensi Kategori Skor Kecemasan Berdasarkan Data Hasil Screening.

\begin{tabular}{ccc}
\hline Skor & Kategori & $\begin{array}{c}\text { Frekuensi (Jumlah pemilik } \\
\text { hewan peliharaan) }\end{array}$ \\
\hline$X<46$ & Rendah & 2 \\
$46-69$ & Sedang & 15 \\
$69-92$ & Tinggi & 5 \\
\hline
\end{tabular}

Berdasarkan jumlah calon subjek yang mengikuti screening test, maka yang peneliti jadikan subjek penelitian adalah pemilik hewan peliharaan (kucing) yang sesuai dengan kriteria penelitian yang sudah peneliti tentukan dan bersedia menjadi subjek penelitian, yakni yang bisa masuk menjadi subjek sebanyak 5 orang dengan kategori tinggi, dari 5 orang tersebut yang sesuai kriteria dan bersedia menjadi subjek penelitian sebanyak 2 orang, yaitu subjek R dan RN. 
Setelah melakukan wawancara diketahui bahwa subjek R memelihara 11 ekor kucing, yang mana 8 diantaranya merupakan kucing ras dan 3 ekornya lagi merupakan kucing domestik/kampung. Saat wawancara sedang berlangsung subjek sambil sesekali memangku dan mengelus kucing yang datang mendekatinya. Kucing subjek R ini terlihat sangat bersih dan terawat, bulu-bulu kucingnya mengembang dan tidak rontok, badan kucingnya juga gemuk. Sehari-harinya subjek merawat kucing-kucingnya ini dengan rutin memberikan makan pada kucingnya, membersihkan kotorannya, memandikan dan memberikan perawatan lainnya seperti memotong kuku ataupun menyisiri bulu-bulu kucingnya.

Subjek R sudah menganggap bahwa kucing yang dipeliharanya selama ini seperti anak sendiri, pernah dalam suatu keadaan dimana kucing subjek hilang, disitu subjek merasa sedih karena tidak dapat menemukan kucingnya walaupun telah berusaha untuk mencarinya. Pada saat kucingnya sakit untuk pertama kalinya subjek merasa kebingungan lalu membawa kucingnya ke dokter hewan. Subjek merasa sangat sedih ketika kucingnya yang sudah hidup lama dengannya meninggal.

Adapun kebahagiaan yang subjek R rasakan setelah memelihara kucing adalah subjek mengatakan bahwa hidupnya terasa lengkap dan sempurna setelah memelihara kucing. Menurutnya apabila dalam sehari saja subjek tidak berinteraksi dengan kucingnya, maka dia akan merasa tidak karuan. Bisanya karena terlalu asik bersama kucingnya saat menggendong atau berbicara dengan kucingnya subjek bisa sampai lupa waktu dan menunda pekerjaan lainnya. Disaat subjek merasa gelisah, dengan kehadiran kucing itu membuat dirinya menjadi bahagia. Adanya kucing membuat suasana rumah subjek menjadi menyenangkan dan tidak sepi. Karena sangat menyukai kucing itu melihat tingkahnya yang lucu-lucu membuat perasaan beban menjadi hilang sejenak. Menggendong sambil berbicara dengan kucingnya seringkali terlalu menyenangkan sampai menyumbuat subjek lupa waktu. Dengan memberi makan dan merawat kucing membuat subjek merasa bermakna dalam hidupnya karena sudah berbagi rezeki dengan hewan. Subjek yakin dengan berbagi pada kucing, menolong dan menyayanginya juga akan membuat subjek mendapatkan kebaikan dan berkah dari Allah. Subjek menekankan bahwa memelihara kucing merupakan hal yang bagus, selama niat dan 
memperlakukannya dengan baik hal itu menjadi bagus dan merasa bahwa segala urusannya dipermudah.

Berikutnya pada subjek RN, berdasarkan hasil wawancara diketahui bahwa subjek memelihara kucing, diawali dari kucing domestik/kampung yang sering datang kerumahnya untuk meminta makan, lalu karena tidak tega sehingga subjek memutuskan untuk mengadopsi kucing liar tersebut, kucing kedua subjek yaitu kucing ras yang didapatkan subjek dari pemberian kepala sekolah di tempat subjek RN mengajar, dan kucing ketiganya didapatkan subjek dari membeli di salah satu pet shop sebagai pasangan kucing rasnya yang sudah ada dirumah.

Gambaran pet attachment pada subjek RN adalah biasanya subjek meluangkan waktu bersama kucingnya di pagi hari, dimana subjek membersihkan kotoran kucingnya dan juga menyapu rumah, disitu subjek sambil mengajak bermain kucingnya dengan melemparkan mainan tikus pada kucingnya, ataupun ada kucingnya yang memainkn lidi, kantong plastik, atau bahkan ada kucingnya yang suka memainkan kotak. Subjek yang berprofesi sebagai guru dan juga mengajar les setelah pulang sekolah biasanya baru pulang ke rumah pada sore hari. Setelah beraktivitas seharian, lelah yang dirasakannya hilang ketika subjek sampai di rumah dan melihat kucing-kucingnya sudah menunggu di depan rumah. Memelihara kucing tidak membuat subjek merasa terbebani, subjek merasa ikhlas dalam memelihara kucing dan menganggapnya seperti anggota keluarga. Memelihara kucing dirasa subjek seperti pengobat hati, menghilangkan stress, dan penghiburnya yang membuatnya betah di rumah.

Cara subjek memelihara kucingnya ialah dengan memberikan kebebasan pada kucingkucingnya, sehingga subjek tidak mengurung kucingnya di dalam kandang sehingga bebas berkeliaran di dalam rumah dan bahkan memberikan akses kucingnya untuk dapat keluar rumah melalui jendela rumah yang sengaja tidak di kunci oleh subjek agar kucingnya dapat keluar melalui jendela tersebut. Hal ini subjek lakukan juga sebagai bentuk untuk melatih kucingnya agar tidak terlalu manja. Bentuk kebersamaan subjek dengan kucingnya itu bermacam-macam, karena sifat kucingnya berbeda-beda, ada yang suka di elus-elus, ada yang tidak suka digendong, ada yang suka di pangku, subjek juga seringkali tidur bersama kucingnya di lantai 1 rumahnya, jadi ada kucingnya yang suka tidur di atas kepala subjek, ada 
yang suka tidur di badan anaknya, ada pula kucing yang suka tidur di kakinya subjek dan bahkan ada juga kucing yang jaga jarak tidak mau terlalu dekat dengan subjek, jadi apabila subjek mengangkat kucingnya tidur di dekatnya maka kucingnya akan pindah lagi ke lantai.

Cara yang dilakukan subjek untuk mengakrabkan diri dengan kucing adalah dengan memberikan makan secara rutin, dengan begitu akan menumbuhkan keparcayaan kucing pada dirinya. Subjek menyukai saat dimana kucingnya mau bermain, karena hal itu menunjukkan bahwa kucingnya bahagia dan tidak stress dipelihara oleh subjek.

Setelah memelihara kucing subjek tidak berpikiran kaku, kemudian juga tidak berpikiran berat terhadap beban hidupnya, melihat kucingnya main stress yang dirasakannya hilang, subjek juga merasa lebih beruntung dibandingkan dengan orang yang tidak memelihara kucing karena mereka dinilai subjek lebih banyak mengeluh, hal ini di karenakan subjek pun dulunya merasakan hal tersebut di waktu sebelum memelihara kucing, subjek sering berkelahi dengan suaminya, banyak mengeluh dan subjek merasakan kehidupannya kaku pada saat sebelum memelihara kucing.

Gambaran kebahagiaan pada subjek RN dapat dilihat bahwa subjek merasa terhibur, dan tidak kesepian karena adanya kucing. Memiliki banyak kucing dan dapat mengenali berbagai macam sifat kucingnya yang berbeda-beda juga membuat subjek merasakan senang. Subjek RN mengatakan bahwa ia akan terus memelihara kucing-kucing semampunya dan mengusahakan yang terbaik bagi kucing. Subjek menginginkan hidupnya menjadi bermanfaat bagi dunia dan akhirat. Hal tersebut merupakan perwujudan dari keinginan subjek RN untuk hidup yang bermanfaat di dunia maupun akhirat nanti. Segala bentuk kepeduliannya terhadap kucing diserahkannya bagaimana Tuhan menilai perbuatannya. Subjek RN juga mengharapkan agar orang-orang di sekitarnya dapat menghargai dan menunjukkan kepedulian terhadap kucing secara khusus dan hewan lainnya secara umum dengan cara peduli atau minimal agar tidak menyakiti mereka. Subjek RN merasakan kepuasan dalam hidupnya setelah merawat kucing dengan baik. Dapat menjaga dan menyayangi kucing-kucingnya sepenuh hati ini membuat subjek merasa puas. 


\section{Pembahasan}

Pet Attachment (kelekatan pada hewan peliharaan) ini didasari pada teori attachment milik Bowlby pada manusia, yang menyatakan bahwa attachment adalah sebagai ikatan emosional yang dimiliki antara individu dengan figur lekatnya. Figur kelekatan disini dapat berupa individu dengan individu lain atau pun figur berupa hewan peliharaan (Hardiana Saraswati Nugrahaeni, 2016). Yang mana pada penelitian ini kelekatan yang terbangun adalah diantara subjek pemilik hewan peliharaan dengan figur lekatnya yaitu kucing. Nebbe menyatakan "The human-pet relationship can be simple and safe, with minimal risk. A pet can be accepting, openly affectionate, honest, loyal and consisten, which are all qualities that can be satisfy a person's basic need to be loved and feel self-worth" (Smolkovic, Fajfar, \& Mlinaric, 2012). Artinya adalah hubungan manusia dan hewan merupakan hubungan yang sederhana dan aman, dengan resiko yang minimal. Hewan peliharaan dapat menerima, terbuka, jujur, setia dan konsisten. Semua kualitas tersebut dapat memenuhi kebutuhan dasar manusia untuk mencintai dan merasa dicintai. Selaras dengan pernyataan ini, bahwa pada kedua subjek merasakan bahwa kucing-kucing mereka dapat merasa tenang bersama kucingnya, tidak pula merasakan kesepian karena keberadaan kucingnya.

Berdasarkan hasil wawancara yang telah dilakukan, bahwa gambaran pet attachment yang ada pada subjek $R$ adalah subjek biasanya memberikan makan pada kucingnya 3 kali sehari, yaitu pada waktu pagi, siang dan sore atau malam hari. Pada saat memberikan makan kucingnya, subjek juga sambil sesekali mengajak kucingnya bicara. Selain memberi makan kucingnya, subjek juga suka bermain bersama dengan kucingnya, sering juga memperhatikan (melihat dari jauh) kucingnya dan apabila nanti nama kucingnya dipanggil maka kucing milik subjek akan melihat kearah subjek. Mengelus-elus dan menyisiri bulu kucingnya juga biasa subjek lakukan, hal lainnya yang subjek lakukan adalah memangku dan menggendong kucingnya. Subjek juga pernah tidur bersama dengan kucingnya. Hal ini selaras dengan aspek kontak fisik pada kriteria penilaian kelekatan, yang mana menyebutkan bahwa individu yang terikat harus memiliki hubungan fisik yang intim seperti saling menatap, pelukan, ciuman dan kontak fisik. Dalam hubungan anjing dan pemilik, hal ini ditunjukkan pemilik dengan secara 
rutin merawat, memangku atau menggendong, terlibat dalam permainan face to face, mencium, dan tidur dengan anjing mereka (Yuniarti, 2008).

Subjek R mengatakan bahwa setelah memelihara kucing keadaan rumahnya menjadi ramai dan tidak lagi merasa kesepian, saking sukanya subjek pada kucing karena melihat tingkahnya yang lucu membuat subjek dapat melupakan masalah yang dialaminya. Dalam aspek kriteria pilihan disampaikan jika pemilihan figur lekat yang familiar, mau mendengar dan memiliki kompetensi dalam mengurangi stress. Dalam penelitiannya pada tahun 1997, Archer menyatakan bahwa para pemilik melaporkan bahwa berinteraksi dengan anjing berbeda dengan interaksi sesama manusia atau manusia dengan hewan lainnya. Hal ini disebabkan karena anjing memberikan respon yang tinggi, menyediakan afeksi tidak bersyarat dan mengurangi stress karena kesepian dan masalah keamanan (Yuniarti, 2008). Subjek sudah menganggap bahwa kucing yang dipeliharanya seperti anaknya sendiri, walaupun begitu kepada kucing lainnya subjek berpandangan bahwa mereka juga merupakan hewan yang patut disayangi.

Subjek R menceritakan bahwa ketika dirinya sedang sakit maka kucing-kucingnya yang biasanya bersikap manja padanya seolah mengerti dan jadinya hanya berdiam diri di dekat subjek dan subjek juga merasa seolah kucingnya memberikan semangat padanya. Ketika bersama dengan kucingnya juga membuat rasa stress karena beban yang subjek pikirkan dapat berkurang. Hal ini termasuk pada aspek efek terhadap kesehatan fisik dan psikologis, yang mengatakan individu yang saling lekat harus mendapatkan keuntungan secara kesehatan dari ikatan yang terjalin. Pemilik anjing harus mendapatkan kesehatan fisik dan psikologis yang baik, sebagai hasil dari efek penenangan psikologis yang dimiliki anjing, serta kesehatan fisik yang relatif tinggi dari kesungguhan dalam pemeliharaan anjing (Yuniarti, 2008). Sehingga keuntungan dari kelekatan disini tidak hanya terjadi dari kelekatan terhadap anjing, namun fakta dilapangan mendapatkan bahwa pemilik kucing juga merasakan dampaknya terhadap kesehatan.

Kemudian gambaran kebahagiaan subjek $\mathrm{R}$ mengatakan bahwa setelah memelihara kucing dia merasakan kebahagiaan yang lengkap dan sempurna dalam hidupnya. Menurut subjek bahwa kucing itu lucu dan melihatnya membuat subjek merasa senang. Subjek juga 
mengatakan bahwa dirinya merasa lebih bersyukur setelah memelihara kucing, hal ini dikarenakan subjek merasa bahwa rezekinya semakin bertambah banyak, dalam menjalani setiap urusan juga dirasakan seolah dipermudah. Bersyukur merupakan komponen penting dalam kebahagiaan (Sofia \& Pusputasari, 2018). Memelihara kucing merupakan suatu emosi positif yang membuat subjek serasa senang, sebagaimana aspek positive emotion yang menyatakan emosi positif dapat tercapai melalui dua sumber; kenikmatan dan kesenangan (Jusmiati, 2017).

Saat bersama dengan kucingnya dalam suatu aktivitas seperti menggendong atau pada saat berbicara dengan kucingnya, subjek jadi lupa waktu dan mengabaikan kegiatan lainnya. Hal ini dapat dijelaskan dengan aspek engagement, yang mana engagement adalah sebuah kondisi jiwa yang hanyut menyatu dalam sebuah aktivitas. Di saat seseorang melakukan sebuah aktifitas, maka seluruh perhatian baik fisik maupun psikis diarahkan secara totalitas terhadap aktifitas tersebut. Akhirnya, tidak ada pikiran lain selain aktifvitasnya (Jusmiati, 2017).

Positive relationship (hubungan positif) atau relasi yang dibentuk dengan orang lain atau dalam masyarakat luas. Orang yang mampu membangun relasi yang baik berdampak positif pada tingkat kebahagiannya. Inilah yang disebut sebagai investasi sosial yang tidak bisa dinilai dengan materi (Jusmiati, 2017). Subjek R menerangkan bahwa dengan memelihara kucing itu tidak berpengaruh dengan bagaimana dirinya berhubungan dengan orang lain, subjek $\mathrm{R}$ menilai bahwa jika ada yang tidak menyukai kucing lebih baik diam saja daripada harus mengurus atau mengatur orang yang memelihara kucing dan berpandangan buruk pada kucing, karena kucing itu tidak mengganggu kita.

Adanya rasa yang lebih bermakna di dalam hidup subjek karena dapat berbagi makanan dengan kucing menjadi suatu kaitan yang erat terhadap kebahagiaan. Semua tindakan yang dilakukan oleh manusia didorong oleh meaning (makna hidup) yang ada dalam dirinya (Jusmiati, 2017). Dari memelihara kucing ini subjek berharap untuk mencari berkahnya Allah, subjek merasakan juga bahwa ada saja rezekinya yang selalu tercukupi untuk memberikan makan kucing-kucingnya. Subjek yakin dengan menolong kucing, memberi makan, menyayangi, maka dirinya juga akan mendapatkan kebaikan karena telah berbuat baik. Subjek yang dapat berbuat baik disini termasuk dalam mendapat rahmat/karunia Allah swt. 
karena dipermudah dalam berbuat kebaikan (Sofia \& Pusputasari, 2018). Apabila kita melihat pada aspek accomplishment, pencapaian sebuah target juga sangat berpengaruh pada tingkat kebahagian seseorang. Hal itu tidak lepas dari sikap optimistis sebelumnya yang menjadi sebuah kenyataan (Jusmiati, 2017), maka subjek termasuk dalam hal ini.

Dalam memelihara kucing ini tentu juga tidak mudah, subjek menyatakan adanya kerepotan di dalam memelihara kucing, diantaranya harus membersihkan kandangnya, memandikan kucing-kucingnya, dan keadaaan dimana saat kucingnya sakit. Walaupun begitu subjek menyadari bahwa itu semua merupakan tantangannya dalam memelihara kucing dan sudah menjadi tanggung jawabnya, sehingga subjek tetap sabar melakukannya. Kesabaran ini merupakan proses pencapaian kebahagiaan yang bersumber dari perilaku yang dilakukan oleh subjek (Sofia \& Pusputasari, 2018).

Berdasarkan pemaparan yang telah disampaikan, peneliti menyimpulkan bahwa peran pet attachment terhadap kebahagiaan pemilik hewan peliharaan pada subjek $\mathrm{R}$ dalam aspek positive emotion merasakan suatu kebahagiaan yang lengkap dan sempurna dalam hidupnya, dari aspek engagement saat subjek bersama dengan kucingnya membuat dirinya lupa waktu dan menunda aktivitasnya yang lain, dalam aspek positive relation yang dialami subjek adalah bahwa dengan memelihara kucing tidak berpengaruh terhadap hubungannya dengan orang lain, jika ada yang tidak menyukai kucing subjek hanya menilai bahwa lebih baik mereka diam saja daripada harus mengatur orang yang memelihara kucing dan berpandangan buruk terhadap kucing. Aspek meaning yang dirasakan subjek $\mathrm{R}$ adalah dirinya yang merasa lebih bermakna dalam hidupnya karena dapat berbagi makanan dengan kucing-kucing, dan untuk aspek accomplishment bahwa subjek dari memelihara kucing ingin mencari berkahnya dari Allah, yaitu subjek merasa mendapatkan kemudahan dalam setiap urusan yang dihadapinya.

Berikutnya adalah gambaran pet attachment pada subjek RN yang peneliti temukan berdasarkan hasil wawancara adalah kebersamaan yang dilakukan subjek bersama dengan kucingnya itu bermacam-macam, ada kucingnya yang suka dipangku, ada yang suka dieluselus oleh subjek, ada juga kucingnya yang tidak suka digendong subjek namun ketika ada subjek kucingnya bersikap manja pada subjek. Biasanya subjek juga tidur bersama dengan kucingnya, subjek mengatakan bahwa kucingnya itu pintar karena tau dengan jam tidurnya 
subjek, jadi pada saat subjeknya tidur kuicngnya pun juga sama tidur seperti subjek. Ada kucingnya yang suka tidur di atas kepala subjek, ada yang tidurnya di atas badan anaknya subjek, ada yang sukanya tidur di kaki subjek. Hal-hal ini merupakan bentuk dari kelekatan yang ada pada subjek RN, sebagaimana jika kita melihat pada aspek kontak fisik yang menyebutkan bahwa individu yang terikat harus memiliki hubungan fisik yang intim seperti saling menatap, pelukan, ciuman dan kontak fisik. Dalam hubungan anjing dan pemilik, hal ini ditunjukkan pemilik dengan secara rutin merawat, memangku atau menggendong, terlibat dalam permainan face to face, mencium, dan tidur dengan anjing mereka (Anastasia Yuniarti, 2008), sehingga jika melihat pada aspek ini, dan fakta di lapangan bahwa hubungan fisik yang intim seperti saling menatap, pelukan, ciuman dan kontak fisik juga terdapat pada hubungan pemilik dan kucingnya.

Subjek RN mengatakan bahwa dirinya beruntung dengan memelihara kucing karena dengan itu dirinya merasakan kesenangan sehingga membuat beban dipikirannya hilang. Hal ini ada sebagaimana pada aspek kriteria pilihan yang menyatakan bahwa figur lekat yang familiar, mau mendengar, memiliki kompetensi dalam mengurangi stress (Yuniarti, 2008). Polosnya kucing yang dinilai subjek, dan dianggap sebagai makhluk yang tidak bisa mengeluh membuat subjek menjadi belajar agar tidak banyak mengeluh. Penurut, manja dan segala tingkah lakunya membuat subjek menjadi senang, dan sebagai hewan yang disukai Nabi Muhammad saw, meyakini jika kucing membawa energi positif.

Jika melihat pada aspek reaksi ketika berpisah dan kehilangan yang menyatakan bahwa individu yang saling lekat harus menyadari bahwa berpisah dari satu sama lain sangat membingungkan. Archer, Winchester dan Carmack dalam penelitiannya menyatakan bahwa para pemilik bereaksi negatif seperti, protes, putus asa dan mengurung diri, ketika anjing mereka mati (Yuniarti, 2008). Dan reaksi negative yang peneliti temukan pada subjek RN adalah rasa sedih yang mucul saat perpisahan itu terjadi atau bahkan saat kucingnya sakit parah dan subjek tidak mampu membawa kucingnya ke dokter, subjek juga yang tidak dapat tidur semalaman saat menghadapi kematian kucingnya.

Selama memelihara kucing, subjek merasa tidak memiliki keluhan seperti temantemannya yang lain, semisal masalah dengan suaminya dulu atau pun merasa anaknya tidak 
menurutinya, subjek tidak merasakan hal tersebut. Subjek juga tidak terlalu berat dalam memikirkan beban hidupnya. Pada aspek efek terhadap kesehatan fisik dan psikologis menjelaskan individu yang saling lekat harus mendapatkan keuntungan secara kesehatan dari ikatan yang terjalin. Pemilik anjing harus mendapatkan kesehatan fisik dan psikologis yang baik, sebagai hasil dari efek penenangan psikologis yang dimiliki anjing, serta kesehatan fisik yang relatif tinggi dari kesungguhan dalam pemeliharaan anjing (Yuniarti, 2008). Berdasarkan penjelasan efek terhadap kesehatan fisik dan psikologis dari pemilik anjing, maka dalam penelitian ini yang peneliti temukan bahwa dengan memiliki kelekatan dengan kucing pun berpengaruh memberikan efek yang baik bagi pemiliknya.

Subjek RN mengatakan dengan adanya kucing membuatnya terhibur dan menjadi tidak kesepian karena ada kucing sebagai temannya. Hal yang subjek rasakan disini merupakan bentuk dari emosi positif yang ditimbulkan dari subjek yang memiliki kelekatan dengan kucingnya, sebagaimana disampaikan bahwa positive emotion (emosi positif) dapat tercapai melalui dua sumber; kenikmatan dan kesenangan. Yang terkait dengan kenikmatan adalah halhal yang bersentuhan dengan fisik atau tubuh, seperti makan yang enak di saat lapar, tidur di saat lelah. Sementara kesenangan lebih berhubungan dengan intelektual dan kreatifitas (Jusmiati, 2017).

Pada saat subjek bersama dengan kucingnya, subjek seperti tidak lagi memikirkan hal lainnya, hal itu juga membuat subjek seperti menunda untuk mengerjakan pekerjaan lain miliknya saat bersama dengan kucingnya. Ini merupakan bentuk dari engagement, engagement adalah sebuah kondisi jiwa yang hanyut menyatu dalam sebuah aktivitas. Di saat seseorang melakukan sebuah aktifitas, maka seluruh perhatian baik fisik maupun psikis diarahkan secara totalitas terhadap aktifitas tersebut. Akhirnya, tidak ada pikiran lain selain aktifvitasnya (Jusmiati, 2017).

Subjek RN memiliki hubungan yang baik pada tetangga di lingkungan sekitarnya, subjek dan kucingnya bisa saling berinteraksi dengan tetangga sekitar, tetangga subjek pun juga bisa memberikan sisa makanan pada kucing-kucing. Positive relationship (hubungan positif) atau relasi yang dibentuk dengan orang lain atau dalam masyarakat luas. Orang yang mampu membangun relasi yang baik berdampak positif pada tingkat kebahagiannya. Inilah yang 
disebut sebagai investasi sosial yang tidak bisa dinilai dengan materi (Jusmiati, 2017). Jika ada yang tidak menyukai kucing pun subjek memaklumi hal tersebut, karena memang tidak semua orang menyukai kucing, selama orang yang tidak menyukai kucing itu tidak menyakiti mereka, subjek biasa saja, namun apabila sampai menyakiti kucing, subjek pun bisa terbawa perasaan emosi.

Subjek RN mengatakan kita yang dapat peduli pada hewan membuat hidup terasa bermakna. Mudahnya subjek untuk dapat melakukan kebaikan atau kebajikan ini merupakan suatu bentuk dari mendapat rahmat atau karunia Allah (Sofia \& Pusputasari, 2018). Mengusahakan untuk dapat menjadi manusia yang bermanfaat di dunia dan akhirat dengan berbuat baik pada kucing merupakan suatu bentuk tindakan yang dilakukan oleh subjek. Sebagaimana meaning dalam kaitanya terhadap kebahagiaan juga sangat erat. Semua tindakan yang dilakukan oleh manusia didorong oleh meaning (makna hidup) yang ada dalam dirinya (Jusmiati, 2017).

Sebagaimana pencapaian sebuah target juga sangat berpengaruh pada tingkat kebahagian seseorang (Jusmiati, 2017), maka dari itu juga subjek merasakan kebahagiaan atas kemudahan yang dirasakannya pada setiap urusannya karena akibat dari memelihara kucing. Selain itu pula orang-orang, tetangga di lingkungan subjek menjadi peduli dan menyayangi kucing.

Jika melihat dari pemaparan yang telah disampaikan, peneliti menyimpulkan bahwa peran pet attachment terhadap kebahagiaan pemilik hewan peliharaan pada subjek RN dari aspek postive emotion bahwa subjek menjadi terhibur dan tidak lagi kesepian karena memiliki kucing, juga karena sifat yang ada pada setiap kucingnya itu bermacam-macam juga membuat subjek menjadi senang, dalam aspek engagement subjek menjadi lupa dengan waktu dan mengabaikan hal-hal lainnya saat bersama dengan kucingnya, pada aspek positive relationship subjek memiliki hubungan yang baik dengan tetangga-tetangganya, tetangga subjek pun juga sayang dan berlaku baik terhadap kucing-kucingnya, maka subjek juga melakukan hal yang sama pada tetangganya, pada orang yang tidak suka dengan kucing pun subjek memaklumi selama orang tersebut tidak menyakiti kucing. Dalam aspek meaning bahwa subjek mengusahakan untuk dapat menjadi manusia yang bermanfaat di dunia dan akhirat, hal itu 
ialah dengan subjek berbuat baik kepada kucing, dan pada aspek accomplishment subjek merasakan bahwa dalam melakukan urusan merasa dipermudah pada setiap prosesnya.

\section{Kesimpulan}

Berdasarkan hasil penelitian dapat disimpulkan bahwa gambaran pet attachment pada pemilik hewan peliharaan jika dilihat pada aspek kontak fisik adalah pemilik hewan peliharaan terlibat dalam bermain bersama dengan kucingnya, memangku dan menggendong, mengeluselus, memandikan serta tidur bersama dengan kucingnya. Kemudian pada aspek kriteria pilihan, yang mana pemilik kucing sudah menganggap kucing seperti anaknya sendiri, juga menganggap bahwa kucing tidak bisa mengeluh dan karena kucing merupakan hewan yang di sukai Nabi Muhammad saw. sehingga dinilai membawa energi positif. Dalam aspek reaksi ketika berpisah dan kehilangan, pada hal ini pemilik hewan peliharaan merasakan sedih bahkan sampai menangis saat berhadapan pada situasi dimana kucingnya hilang, sakit parah dan meninggal. Pemilik kucing juga selalu membungkuskan kain pada kucingnya yang meninggal sebelum di kuburkan. Selain itu, pemilik kucing juga tetap berusaha berfikir positif saat kehilangan kucingnya, bahwa kucingnya akan tetap disayangi oleh orang yang mengambilnya. Pada aspek efek terhadap kesehatan fisik dan psikologis, keadaan dimana pemilik kucing merasakan emosi positif saat bersama dengan kucingnya. Kondisi ini dirasa bermanfaat oleh pemilik kucing ketika dalam kondisi sakit. Pemilik kucing ini seperti mendapatkan semangat baru dari kucingnya, dan juga merasa kucingnya terus menemaninya beristirahat.

Adapun gambaran kebahagiaan pada pemilik hewan peliharaan dapat dilihat dari aspek kebahagiaan, yaitu muncul aspek positive emotion (emosi positif), engagement (kelekatan), positive relationship (hubungan positif), meaning (hidup yang bermakna) dan accomplishment (pencapaian). Selain itu dapat digambarkan berdasarkan aspek kebahagiaan dalam islam yang meliputi mendapat/karunia Allah swt, amal saleh (berbuat baik), bersabar dan bersyukur. Keseluruhan aspek tersebut terpenuhi dari adanya kelekatan pada hewan peliharaan (pet attachment) sehingga menimbulkan kebahagiaan pada kedua subjek. 
Saran

Saran-saran yang diberikan peneliti bagi peneliti berikutnya yaitu untuk dapat memperkaya referensi terkait, terutama referensi terkait pet attachment (kelekatan pada hewan peliharaan) yang masih sangat sedikit untuk dapat ditemukan karena masih sangat jarang diteliti di Indonesia. Kemudian peneliti juga bisa memperbanyak subjek penelitian karena bisa saja ada subjek yang menolak untuk di wawancarai. Dalam hal ini juga disarankan untuk peneliti selanjutnya untuk menggunakan observasi partisipan agar terlibat lebih jauh dalam aktivitas subjek untuk mendapati data yang semakin kaya. Bagi subjek penelitian disarankan untuk dapat terus komitmen dalam memelihara kucing-kucingnya dan tetap terus bertanggung jawab dalam merawat dan menyayangi kucing-kucingnya. Untuk masyarakat umum, terutama

yang sering merasakan stress dan beban hidup yang berat, melihat dari hasil penelitian bahwa memiliki kelekatan terhadap hewan peliharaan berdampak baik terhadap kebahagiaan pemiliknya, maka peneliti menyarakan untuk dapat mencoba membangun komitmen dalam memelihara hewan peliharaan sebagai bagian untuk menambah kebahagiaan dalam hidup.

\section{Referensi}

Hardiana Saraswati Nugrahaeni. (2016). Hubungan Antara Pet Attachment Dengan Kualitas Hidup Pada Pemilik Hewan Peliharaan. Universitas Negeri Semarang.

Herdiansyah, H. (2015). Metodologi Penellitian Kualitatif Untuk Ilmu Psikologi. Jakarta: Salemba Humanika.

Jusmiati. (2017). Kosep Kebahagiaan Martin Seligman: Sebuah Penelitian Awal. Jurnal Rausyan Fiqr, 13( 2).

Kiki. (2019). Mueza. https://www.muidkijakarta.or.id/mueezal.

Margono. (2007). Metodologi Penelitian Pendidikan. Jakarta: PT Rineka Cipta.

Nurlayli, R. K., \& Hidayati, D. S. (2014). Kesepian Pemilik Hewan Peliharaan yang Tinggal Terpisah Dari Keluarga. Jurnal Ilmiah Psikologi Terapan, 02 ( 01).

Rahmadi. (2011). Pengantar Metodologi Penelitian. Banjarmasin: Antasari Press.

Smolkovic, I., Fajfar, M., \& Mlinaric, V. (2012). Attachment To Pets And Interpersonal Relationship. Journal of European Psychology Students, 3.

Sofia, N., \& Pusputasari, E. (2018). Indikator Kebahagiaan (Al-Sa'adah) dalam Perspektif AlQur'an dan Hadits. Psikologika: Jurnal Pemikiran dan Penelitian Psikologi, 23(2).

Yuniarti, A. (2008). Hubungan Antara Kelekatan Terhadap Anjing Peliharaan Dengan Kompetensi Interpersonal Pemiliknya. Universitas Sanata Dharma. 


\begin{tabular}{|l|l|l|l|l|}
\hline Submit & Review & Revisi & Diterima & Publis \\
\hline $26-02-2020$ & - & - & $29-03-2021$ & $30-03-2021$ \\
\hline
\end{tabular}

Arief Tribudiman, Rahmadi, dan Mahdia Fadhila

Program Studi Psikologi Islam

Fakultas Ushuluddin dan Humaniora

Universitas Islam Negeri Antasari Banjarmasin

Email: 3budiman@gmail.com 